\title{
Arbuscular mycorrhizal symbiosis facilitates apricot seedling (Prunus sibirica L.) growth and photosynthesis in northwest China
}

\author{
Yinli Bi ${ }^{1,2}$ - Linlin Xie ${ }^{1} \cdot$ Zhigang Wang $^{1} \cdot K_{\text {Kun Wang }}{ }^{1} \cdot$ Wenwen Liu $^{1} \cdot$ \\ Wenwu Xie ${ }^{1}$
}

Received: 3 March 2020/Revised: 28 June 2020/Accepted: 5 January 2021 / Published online: 2 February 2021

(C) The Author(s) 2021

\begin{abstract}
Arbuscular mycorrhizal (AM) fungi can successfully enhance photosynthesis $\left(P_{\mathrm{n}}\right)$ and plants growth in agricultural or grassland ecosystems. However, how the symbionts affect species restoration in sunlight-intensive areas remains largely unexplored. Therefore, this study's objective was to assess the effect of AM fungi on apricot seedling physiology, within a specific time period, in northwest China. In 2010, an experimental field was established in Shaanxi Province, northwest China. The experimental treatments included two AM fungi inoculation levels ( 0 or $100 \mathrm{~g}$ of AM fungal inoculum per seedling), three shade levels $\left(1900,1100\right.$, and $\left.550 \mu \mathrm{mol} \mathrm{m}{ }^{-2} \mathrm{~s}^{-1}\right)$, and three ages $(1,3$, and 5 years) of transplantation. We examined growth, $P_{\mathrm{n}}$, and morphological indicators of apricot (Prunus sibirica L.) seedling performances in 2011, 2013, and 2015. The colonization rate in mycorrhizal seedlings with similar amounts of shade is higher than the corresponding controls. The mycorrhizal seedling biomass is significantly higher than the corresponding nonmycorrhizal seedling biomass. Generally, $P_{\mathrm{n}}$, stomatal conductance $\left(G_{\mathrm{s}}\right)$, transpiration rate $\left(T_{\mathrm{r}}\right)$, and water use efficiency are also significantly higher in the mycorrhizal seedlings. Moreover, mycorrhizal seedlings with light shade (LS) have the highest $P_{\mathrm{n}}$. WUE is increased in non-mycorrhizal seedlings because of the reduction in $T_{\mathrm{r}}$, while $T_{\mathrm{r}}$ is increased in mycorrhizal seedlings with shade. There is a significant increase in the $\mathrm{N}, \mathrm{P}$, and $\mathrm{K}$ fractions detected in roots compared with shoots. This means that LS had apparent benefits for mycorrhizal seedlings. Our results also indicate that AM fungi, combined with LS, exert a positive effect on apricot behavior.
\end{abstract}

Keywords Apricot seedlings $\cdot$ Arbuscular mycorrhizal symbiosis $\cdot$ Plant growth $\cdot$ Light shade $\cdot$ Photosynthesis

Supplementary Information The online version contains supplementary material available at https://doi.org/10.1007/s40789021-00408-6.

Yinli Bi

ylbi88@126.com

1 State Key Laboratory of Coal Resources and Safe Mining, China University of Mining and Technology (Beijing), Beijing 100083, China

2 Institute of Ecological Environment Restoration in Mine Areas of West China, Xi' an University of Science and Technology, Xi'an 710054, Shaanxi, China

\section{Introduction}

Coal has been the primary source of energy for a long time in China. However, as the primary mining method in northwest China, underground mining causes severe land degradation and soil erosion in mining subsidence areas (Lechner et al. 2016; Wang et al. 2017). The reconstruction of vegetation is an effective way to reduce runoff and soil erosion and is key to restoring ecosystems in ecologically sensitive regions (Jia et al. 2020). Microbial remediation technology is considered an efficient and low-cost ecological remediation method. A previous study has shown that arbuscular mycorrhizal (AM) fungi were crucial for vegetation restoration, significantly enhanced the long-term success of mine site reclamation, and promoted the formation of an eco-environment. (Levy and Cumming 2014; 
Bi et al. 2018, 2019, 2020; Zhang et al. 2020). Therefore, determining how AMF inoculation alters plant growth is vital for promoting sustainable development and ecological restoration in the reclaimed mining area.

Arbuscular mycorrhizal (AM) fungi establish symbiotic associations with $90 \%$ of the terrestrial plant species. These associations are successfully developed within roots and extend into the soil, allowing for mineral nutrients to be assimilated by hyphae and transported to the host plants (Allen and Allen 1980; Mehrotra 1998; Püschel et al. 2008; Levy and Cumming 2014). In turn, the obligate symbionts received carbohydrates from the host plants (Augé 2001; Püschel et al. 2008; Smith et al. 2010). Fungal hyphae improve soil moisture by increasing the contact area between soil and roots, leading to higher organic agent excretion and more significant soil aggregate formation (Augé 2001; Kaschuk et al. 2009; Smith et al. 2010). Moreover, numerous studies reported that the AM fungi affected plant morphology, especially roots (Espeleta et al. 2009; Carminati 2013). Thus, AM symbionts reinforce soil structure, water and nutrient utilization, and photosynthesis in adverse environments (Heinemeyer et al. 2004; Landis et al. 2004, 2005; Hodge and Fitter 2010; Becklin et al. 2012; Binu et al. 2015).

Prunus sibirica L. is a type of shrub with ornamental and medicinal value, and ecological function, mainly distributed in northwest China. This species plays a vital role in the defense against wind and soil erosion and is considered an economic revegetation species that is widely used in the land reclamation of mining areas. Prunus sibirica $\mathrm{L}$. is an economic tree species that is utilized in land reclamation of mining areas. It grows fast and is reasonably tolerant to drought-prone areas, which is particularly suitable for the revegetation of coal mining subsidence areas.

Light is a principal factor that stimulates photosynthetic activities, and various suitable conditions influence photosynthesis in response to different light intensities (Lichtenthaler et al. 1981). Depending on the amounts of light available during growth, plants possess the ability to react with two distinctive growth-responses in natural ecosystems. These include the strong light growth-response as found at high quanta affluence rates with sun leaves of trees or high light plants; and the weak-light growth-response, which is seen in shade leaves and low light plants (Boardman 1977). The ability of plants and chloroplasts to adapt to light is central to the basic growth-response associated with specific changes in morphology, physiology, biochemistry, and leaf and chloroplast structure ( $\mathrm{Yu}$ et al. 1994; Heinemeyer et al. 2004; Yan et al. 2004).

Compared with the shade plants, high light plant leaves are often characterized by thicker and small leaf area, longer palisade cells, a higher cutin, lipid, and starch content per dry weight, a higher dry weight per leaf and leaf area unit, on average. There is also a higher chloroplast and carotenoid content (per unit leaf area), but lower levels on a dry weight basis, a higher prenylquinone content, a higher stomata density, a higher chloroplast content, increased $\mathrm{CO}_{2}$-fixation rates and higher light saturation of photosynthesis, and higher soluble carbohydrates and respiration rates (Lichtenthaler et al. 1981; Yu et al. 1994; Boardman 1977; Heinemeyer et al. 2004; Yan et al. 2004). However, the photosynthetic apparatus of sun leaves is adapted for high rates of photosynthetic light quanta conversion. It exhibits a higher photosynthetic capacity on a chlorophyll and chloroplast basis and different chemical composition and ultrastructure than the shade-type chloroplast of shade leaves (Boardman 1977; Lichtenthaler et al. 1981). Thus, the appropriate light intensity helps plants allocate photosynthetic products in above- or belowground portions, partly facilitating root length elongation and leaf expansion (Wielicki et al. 1995). In turn, strong light results in leaf scorch, or weak light induces flower abscissions, which indirectly delay photosynthesis and $G_{\mathrm{s}}$ (Kubien et al. 2003; Niinemets and Valladares 2004). Particularly, light threatens growth, especially in seriously desertified areas, and has become a significant challenge for species production (Wielicki et al. 1995; Niinemets 2007).

However, how these symbionts affect plant organ growth and photosynthetic characteristics under different light conditions remains mostly unexplored. Thus, it is necessary to investigate relationships between growth and $P_{\mathrm{n}}$ upon AM fungi and shade interactions in specific locations. In the present study, apricot was widely distributed in northwest China in the desterilized areas. Because of large fluctuations in light intensity, apricot was treated with AM inoculum and shade to alleviate the negative effect on species growth. The goal of this study was to address: (i) how AM fungi regulated apricot growth, specifically roots and leaves, productivity, or nutrients; and (ii) how different shade levels affected photosynthetic parameters.

\section{Materials and methods}

\subsection{Study location}

Fieldwork with apricot seedlings (Prunus sibirica L.) was conducted April 1, 2010 to October 30, 2015 in the coal mining subsidence area $\left(39^{\circ} 18^{\prime} 42^{\prime \prime} \mathrm{N}, 110^{\circ} 4^{\prime} 16^{\prime \prime} \mathrm{E}\right)$ located in Daliuta Town, Shenmu County, Yulin City, Shaanxi Province, northwest China (Fig. 1). This study site is located at an altitude of $1200 \mathrm{~m}$ above sea level (m.a.s.l), which is a typical provincial junction of Shanxi, Shaanxi, 


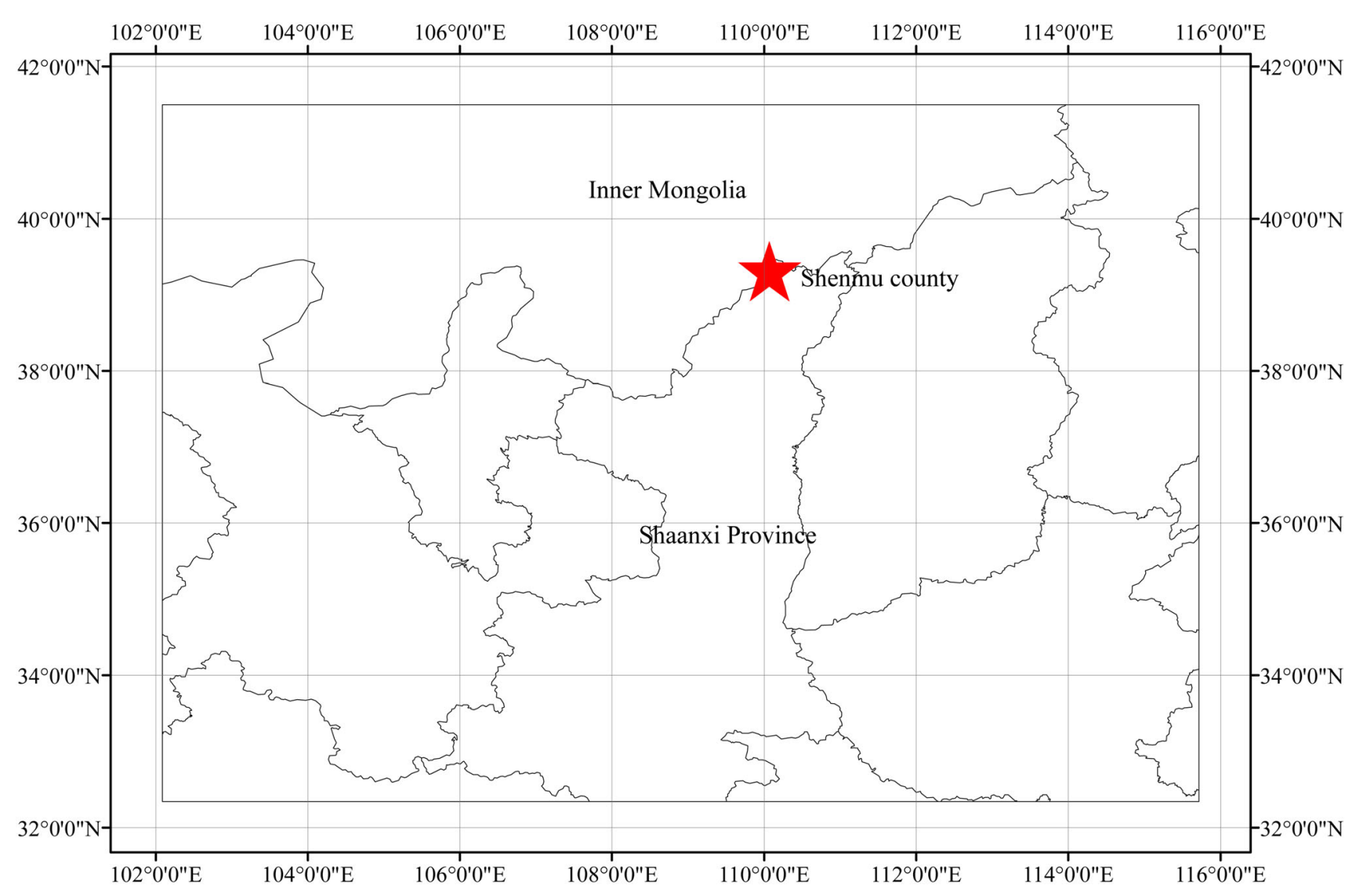

Fig. 1 Sampling site in Daliuta Town, Shenmu County, Shaanxi Province, China

and Inner Mongolia as well as Mu Us desert, the south margin of the Loess Plateau transition zone. According to Shenmu County Meteorological Station, about $70 \%$ of precipitation in this area falls from June to September, and the 10-year average total precipitation and potential evaporation are 150 and $2000 \mathrm{~mm}$, respectively. The study site has a typically arid continental climate, with a mean annual temperature of $8{ }^{\circ} \mathrm{C}$. Cumulative temperatures above $0{ }^{\circ} \mathrm{C}$ and $10{ }^{\circ} \mathrm{C}$ are $3,550{ }^{\circ} \mathrm{C}$ and $3,210{ }^{\circ} \mathrm{C}$, respectively. The annual frost-free period is 150 days, and the total solar radiation is $6000 \mathrm{MJ} / \mathrm{m}$ per year. Soil, consisting of $75 \%$ sand, $22 \%$ silt, and $3 \%$ clay, is classified as Aeolian sandy (FAO/UNESCO 1988), and its physicochemical properties in the soil $(0-20 \mathrm{~cm})$ are as follows: $\mathrm{pH} 7.9$ (1:2.5 for soil: distilled water), soil organic matter (SOM) $4.5 \mathrm{~g} / \mathrm{kg}$, total nitrogen $(\mathrm{N}) 0.21 \mathrm{~g} / \mathrm{kg}$, Olsen phosphorus (P) $5.3 \mathrm{mg} / \mathrm{kg}$ and available potassium (K) $37.8 \mathrm{mg} / \mathrm{kg}$.

\subsection{Preparation of AM fungal inoculum}

AM fungal spores were collected in the dry season from the rhizosphere of Siberian apricot seedlings by the wet sieving and decanting method. Most spores belonged to the Funneliformis mosseae BGCXJ01. Spores were cultured on plants of maize (Zea mays L.) and maintained for 12 weeks. AM fungal inoculum added to apricot seedlings consisted of sandy soils, spores (15-20 spores/g), colonized root fragments (40 root fragments per gram of AM fungal inoculum and $85 \%$ root colonization rate), and external mycelium. Moreover, $100 \mathrm{~g}$ of AM fungal inoculum was added near individual apricot seedling roots. To minimize the indigenous microorganism-induced effects on seedlings, non-mycorrhizal seedlings were also given sterilized inoculum autoclaved at $121^{\circ} \mathrm{C}$ for $2 \mathrm{~h}$. Additionally, to minimize natural environmental variation, the culture soil was excavated from a similar habitat where apricots naturally grow. The apparatus, such as a spade, bag, and balance, were wiped and sterilized using 95\% ethyl alcohol solution before AM fungal inoculation.

\subsection{Experimental design and management}

A three-factor, completely randomized experimental design was used in this study. The first factor was AM fungus inoculum, including two inoculation levels $(0$ or $100 \mathrm{~g}$ of AM fungal inoculum per seedling). The second factor was light intensity, including three shade levels NS (natural shade), LS (light shade), and DS (deep shade) were 
1900,1100 , and $550 \mu \mathrm{mol} \mathrm{m} \mathrm{m}^{-2} \mathrm{~s}^{-1}$, respectively), and the third factor was the transplanted apricot age $(1,3$, and 5 years). Therefore, there were 18 experimental treatments with 54 field plots, including two AM fungus inoculum levels, three light shade levels, and three transplantation ages (Table 1). Each treatment included three replicates, with an area of $240 \mathrm{~m}^{2}$ for each plot $(12 \mathrm{~m} \times 20 \mathrm{~m})$ (Fig. S1). Each plot consisted of six rows, with 10 seedlings per row at a row spacing of $2 \mathrm{~m}$, to minimize mutual interference.

Each shade plot was supported by wooden pillars $(2 \mathrm{~m}$ tall) in four corners and covered with black shade nylon mesh on top of pillars, and light intensity was measured using a PR1010 spectral radiometer (Macam Photometeric Ltd., Livingston, UK). Two photosynthetically active radiation (PAR) sensors were placed in each plot. Light intensity was recorded every $30 \mathrm{~min}$ in shade plots using a small weather station (Delta-T Devices Ltd., Cambridge, UK) on cloudless and windless days in July as reference data. Soil surface temperature was monitored using thermometer probes (Delta-T Devices Ltd.). The experimental field was not given chemical fertilizer or manure, which suggested that no extra available nutrients were provided. When apricot seedlings reached $40 \mathrm{~cm}$ in height, and the crown diameter was $1 \mathrm{~cm}$, seedlings were obtained from the Shenmu Country Forest Department and transplanted

Table 1 Experimental treatment applied to both AMF inoculums addition and shade with nylon mesh with three transplanted ages of apricot seedlings

\begin{tabular}{lccl}
\hline Treatment & $\begin{array}{l}\text { AMF inoculums } \\
\text { (g per plant) }\end{array}$ & $\begin{array}{l}\text { Shade level } \\
\left(\mu \mathrm{mol} \mathrm{m}^{-2} \mathrm{~s}^{-1}\right)\end{array}$ & $\begin{array}{l}\text { Transplanted } \\
\text { ages (years) }\end{array}$ \\
\hline 1 & 0 & $1900(\mathrm{NS})$ & $1(2011)$ \\
2 & 0 & $1900(\mathrm{NS})$ & $3(2013)$ \\
3 & 0 & $1900(\mathrm{NS})$ & $5(2015)$ \\
4 & 0 & $1100(\mathrm{LS})$ & $1(2011)$ \\
5 & 0 & $1100(\mathrm{LS})$ & $3(2013)$ \\
6 & 0 & $1100(\mathrm{LS})$ & $5(2015)$ \\
7 & 0 & $550(\mathrm{DS})$ & $1(2011)$ \\
8 & 0 & $550(\mathrm{DS})$ & $3(2013)$ \\
9 & 0 & $550(\mathrm{DS})$ & $5(2015)$ \\
10 & 100 & $1900(\mathrm{NS})$ & $1(2011)$ \\
11 & 100 & $1900(\mathrm{NS})$ & $3(2013)$ \\
12 & 100 & $1900(\mathrm{NS})$ & $5(2015)$ \\
13 & 100 & $1100(\mathrm{LS})$ & $1(2011)$ \\
14 & 100 & $1100(\mathrm{LS})$ & $3(2013)$ \\
15 & 100 & $1100(\mathrm{LS})$ & $5(2015)$ \\
16 & 100 & $550(\mathrm{DS})$ & $1(2011)$ \\
17 & 100 & $550(\mathrm{DS})$ & $3(2013)$ \\
18 & 100 & $550(\mathrm{DS})$ & $5(2015)$ \\
\hline & & &
\end{tabular}

into the experimental field. The daily temperature was $8-10{ }^{\circ} \mathrm{C}$ during the transplantation period, and relative humidity was $15 \%$ at the end of March 2010. Initially, the location was dominated by Clematis fruticosa and other shrub species, which were occasionally cut to minimize the effects of weeds on apricot seedling growth.

\subsection{Measurement of apricot seedling traits}

Apricot seedlings were harvested on July, 2011, July, 2013, and July, 2015. Seedling size, biomass, and growth were determined as follows: the total shoot height and root collar diameter were measured using a graduated meter and digital caliper, respectively. The number of fully developed leaves was assessed to determine the effect of shade on seedling development, and leaf surface area was measured using a leaf area meter (ADC Bio-Scientific). Apricot seedlings were excavated and divided into coarse or fine roots, stems, and leaves. Subsequently, raw materials were oven-dried at $75{ }^{\circ} \mathrm{C}$ to a constant weight, and the corresponding dry mass was measured and averaged. Finally, mass fractions of apricot seedling leaves, stems, fine $(<2 \mathrm{~mm}$ in diameter) and coarse $(>2 \mathrm{~mm}$ in diameter $)$ roots [(dry mass.dry plant mass $\left.\left.{ }^{-1}, \mathrm{~g} \mathrm{~g}^{-1}\right)\right]$, leaf area ratio [leaf area $\left(\mathrm{cm}^{2}\right)$.plant dry mass $\left.{ }^{-1}\left(\mathrm{~g}^{-1}\right)\right]$, specific leaf area [leaf area $\left(\mathrm{cm}^{2}\right) \cdot$ leaf dry mass ${ }^{-1}\left(\mathrm{~g}^{-1}\right)$ ] and root/shoot ratio were calculated according to the Hunt's (1997) method (Hunt and Cornelissen 1997). The total root length was estimated using the gridline intersection method (Tennant 1975).

\subsection{Sampling and determination of seedlings}

Apricot seedling mineral status in shoots and roots was determined. After seedling fractions were naturally dried, the raw materials were oven-dried at $75{ }^{\circ} \mathrm{C}$ for $48 \mathrm{~h}$ and ground. Nitrogen $(\mathrm{N})$, phosphorus $(\mathrm{P})$, and potassium (K) content in different plant material parts was oven-dried and determined after digestion in a mixture of concentrated $\mathrm{H}_{2} \mathrm{SO}_{4}$ and $\mathrm{H}_{2} \mathrm{O}_{2}$. $\mathrm{N}$ content was measured using the micro-Kjeldahl procedure with $5 \mathrm{~mL}$ digestion solution, $\mathrm{P}$ content was determined using the vanadomolydate method, and $\mathrm{K}$ content was examined using flame photometry (Wang et al. 2015).

\subsection{AM colonization}

The calculation of AM colonization was used in the gridline intersection method (Giovannetti and Mosse 1980). Root sub-samples (non-supersized) were collected, cleared with $10 \% \mathrm{KOH}$ solution, and stained with $0.01 \%$ trypan blue in lacto-glycerol (Brundrett 2004). Then the roots were cut into $1 \mathrm{~cm}$ pieces, and nine root pieces were 
mounted lengthwise on a microscope slide and examined at three (400× magnification) locations (top, middle, and bottom) for each replicate. The colonization rate was calculated as the percentage of colonized root length. Total fractional colonization and those of arbuscules, vesicles, and internal hyphae in the root cortex were recorded. In addition, mycorrhizal responsiveness was expressed as the ratio of the total dry weight of mycorrhizal and non-mycorrhizal plants. The shade treatment response index was calculated as the ratio of the total dry weight of species exposed to natural light and species under shade conditions.

\subsection{Leaf gas exchange measurements}

Six apricot seedlings were measured in each plot. Gas exchange was measured using a portable photosynthesis system (Li-6400; Li-Cor Inc., Lincoln, NE, USA), including $P_{\mathrm{n}}, G_{\mathrm{s}}, T_{\mathrm{r}}$, and intercellular $\mathrm{CO}_{2}$ concentration with fully expanded sun-exposed leaves on clear, cloudless, and windless days. The system was operated in an open flow mode with $6 \mathrm{~cm}^{2}$ leaf chambers and an integrated $\mathrm{CO}_{2}$ supply system, which should be performed in a steady-state under conditions of saturated light intensity $\left(1200 \mu \mathrm{mol} \mathrm{m} \mathrm{m}^{-2} \mathrm{~s}^{-1}\right)$ and $400 \mathrm{ppm} \mathrm{CO}_{2}$. Midday air temperature ranged from 26 to $35^{\circ} \mathrm{C}$, and water vapor pressure ranged from 1.5 to $3 \mathrm{kPa}$. Specifically, diurnal net assimilation and $G_{\mathrm{s}}$, together with micro-climate variables such as photosynthetic quantum flux density, air and leaf temperatures, relative humidity, and ambient $\mathrm{CO}_{2}$ concentration, of three to four sunlit leaves were measured in situ every $30 \mathrm{~min}$ from early morning to sunset. The leaf chamber was attached to the Peltier-cooling system immediately before measurement to maintain near ambient chamber temperature. The sunlit leaves were randomly selected using the following criteria: (i) leaves were located at the outer portions of a branch on the upper canopy; (ii) leaves were intact and undamaged; and (iii) leaves were similar to surrounding leaves. After the measurements were completed, the monitored leaves were harvested, and leaf area was measured using a leaf area meter (Li-3100; Li-Cor Inc.). A sub-sample was then punched out from leaf lamina to determine leaf mass per area (LMA, g/m $\left.{ }^{2}\right)(1.5 \mathrm{~cm}$ in diameter leaf discs) after drying at $75^{\circ} \mathrm{C}$.

\subsection{Statistical analysis}

Before statistical analysis, data normality and homoscedasticity were tested using the KolmogorovSmirnov test, and square root or natural-log transformation was used as necessary. The potential effects of three main factors on apricot seedlings were tested. A three-way analysis was used to evaluate the significance among AM fungi, shade, and age. A two-way ANOVA was applied for two random factors of apricot seedling traits, including AM fungi and shade, AM fungi and age, or shade and age interactions with least significant differences (LSD) for multiple comparisons at $P<0.05$. Specifically, repeatedmeasured ANOVA was used to examine the effect of transplantation age on all the monitored parameters. Multiple comparisons were performed using SAS 8.0 (SAS Campus Drive Cary, NC, USA) by LSD at $P<0.05$. The figures were obtained using Sigma-Plot 11.0 (San Jose, CA, USA).

\section{Results}

\subsection{Morphological characteristics of seedlings}

Most plant functions were significantly affected by the presence of mycorrhizae and seedling age, while the shade did not cause significant variations in most plant functions. However, interactions between mycorrhizae and shade significantly affected several traits, which were related to performance of below-ground plant parts (Table 2). Apricot seedlings were shade-responsive and seedlings with NS and DS response index were $8 \%-15 \%$ and $5 \%-16 \%$ smaller than non-mycorrhizal or mycorrhizal seedlings, respectively, and the shade responsiveness was much higher in LS (Fig. 2). For the three transplantation ages with mycorrhiza seedlings, the mycorrhizal responsiveness was around $60 \%$ for seedlings exposed to LS, and it was only around $40 \%$ of mycorrhizal responsiveness for NS or DS. Mycorrhizal responsiveness was increased when the experimental duration was extended. Both larger leaf area and higher $P_{\mathrm{n}}$ per unit contributed to an increase in seedling dry mass. Higher $P_{\mathrm{n}}$ was consistent with higher $\mathrm{N}$ and $\mathrm{P}$ fractions in mycorrhizal seedlings. Root dry mass of mycorrhizal seedlings was $42 \%$ higher than non-mycorrhizal seedlings. Significant interactions existed between LS and mycorrhiza.

\subsection{Plant nutrients}

Nutrient mass fractions in shoots and roots were significantly associated with transplantation ages $(\mathrm{N}, \mathrm{P}$, and $\mathrm{K}$ ) and mycorrhiza ( $\mathrm{P}$ and $\mathrm{K}$ ) (Table $\mathrm{S} 1$ ). $\mathrm{P}$ and $\mathrm{K}$ mass fractions in roots were higher compared with mycorrhiza seedling shoots. Interactions between mycorrhiza and shade were significant for $\mathrm{N}, \mathrm{P}$, and $\mathrm{K}$ in shoots and roots, the interaction between age and mycorrhiza was significant for $\mathrm{N}$ in shoots and $\mathrm{P}$ in roots, the interaction between age and shade was significant for $\mathrm{N}$ in roots, and the interaction among seedling age, mycorrhiza and shade was significant for $\mathrm{K}$ in shoots (Table S1). Overall, apricot seedlings had 
Table 2 The ANOVA table shows the effect of AMF and shade treatments of plant traits on apricot seedlings

\begin{tabular}{|c|c|c|c|c|c|c|c|c|}
\hline \multirow[t]{2}{*}{ Parameters } & \multicolumn{2}{|l|}{ Age } & \multicolumn{2}{|l|}{$\mathrm{AMF}$} & \multicolumn{2}{|c|}{ Shade } & \multicolumn{2}{|c|}{ AMF $\times$ Shade } \\
\hline & $F$ & $P$ & $F$ & $P$ & $F$ & $P$ & $F$ & $P$ \\
\hline Height (mm) & 56.2 & $<\mathbf{0 . 0 0 1}$ & 9.26 & 0.001 & 0.86 & 0.327 & 24.3 & $<\mathbf{0 . 0 0 1}$ \\
\hline Crown diameter $(\mathrm{cm})$ & 38.7 & $<\mathbf{0 . 0 0 1}$ & 13 & $<\mathbf{0 . 0 0 1}$ & 29.5 & $<0.001$ & 36.8 & $<\mathbf{0 . 0 0 1}$ \\
\hline Leaf number & 97.3 & $<\mathbf{0 . 0 0 1}$ & 30.5 & $<\mathbf{0 . 0 0 1}$ & 0.23 & 0.527 & 20.1 & $<\mathbf{0 . 0 0 1}$ \\
\hline Leaf area $\left(\mathrm{cm}^{2}\right)$ & 28.5 & $<\mathbf{0 . 0 0 1}$ & 4.53 & 0.029 & 8.77 & $<0.001$ & 13.2 & $<\mathbf{0 . 0 0 1}$ \\
\hline Root length (mm) & 8.47 & $<\mathbf{0 . 0 0 1}$ & 16.6 & $<\mathbf{0 . 0 0 1}$ & 9.88 & $<0.001$ & 11.8 & $<\mathbf{0 . 0 0 1}$ \\
\hline Leaf dry mass (g) & 16.2 & $<\mathbf{0 . 0 0 1}$ & 15.5 & $<\mathbf{0 . 0 0 1}$ & 0.85 & 0.257 & 6.21 & 0.003 \\
\hline Shoot dry mass (g) & 22.2 & $<0.001$ & 13.5 & $<\mathbf{0 . 0 0 1}$ & 0.46 & 0.635 & 6.43 & 0.002 \\
\hline Root dry mass (g) & 131 & $<\mathbf{0 . 0 0 1}$ & 85.2 & $<\mathbf{0 . 0 0 1}$ & 8.64 & 0.004 & 28.7 & $<\mathbf{0 . 0 0 1}$ \\
\hline Plant dry mass (g) & 26.8 & $<\mathbf{0 . 0 0 1}$ & 38.6 & $<\mathbf{0 . 0 0 1}$ & 13.2 & $<0.001$ & 25.4 & $<0.001$ \\
\hline Leaf area ratio $\left(\mathrm{cm}^{2} / \mathrm{g}\right)$ & 8.32 & 0.005 & 6.24 & 0.012 & 0.52 & 0.486 & 13.1 & $<\mathbf{0 . 0 0 1}$ \\
\hline Root/shoot (g/g) & 1.23 & 0.265 & 8.55 & 0.005 & 4.24 & 0.011 & 15.2 & $<\mathbf{0 . 0 0 1}$ \\
\hline Root length (mm/g) & 13.3 & $<\mathbf{0 . 0 0 1}$ & 20.3 & $<\mathbf{0 . 0 0 1}$ & 1.88 & 0.161 & 12.7 & $<\mathbf{0 . 0 0 1}$ \\
\hline Stomatal conductance $\left(\mathrm{mmol} \mathrm{m} \mathrm{m}^{-2} \mathrm{~s}^{-1}\right)$ & 18.3 & $<\mathbf{0 . 0 0 1}$ & 14.7 & $<\mathbf{0 . 0 0 1}$ & 22.7 & $<\mathbf{0 . 0 0 1}$ & 12.7 & $<\mathbf{0 . 0 0 1}$ \\
\hline Shoot N (\%) & 8.21 & 0.001 & 1.23 & 0.228 & 1.35 & 0.215 & 20.3 & $<\mathbf{0 . 0 0 1}$ \\
\hline Root N (\%) & 36.2 & $<0.001$ & 1.5 & 0.096 & 1.89 & 0.085 & 51.2 & $<\mathbf{0 . 0 0 1}$ \\
\hline Shoot P (\%) & 28.7 & $<\mathbf{0 . 0 0 1}$ & 23.2 & $<0.001$ & 1.27 & 0.245 & 15.9 & $<\mathbf{0 . 0 0 1}$ \\
\hline Root P (\%) & 33.2 & $<\mathbf{0 . 0 0 1}$ & 18.6 & $<0.001$ & 1.25 & 0.276 & 16.7 & $<0.001$ \\
\hline Shoot K (\%) & 78.7 & $<0.001$ & 84.3 & $<0.001$ & 1.59 & 0.186 & 13.3 & $<0.001$ \\
\hline Root K (\%) & 168 & $<0.001$ & 51.3 & $<0.001$ & 1.68 & 0.155 & 15.4 & $<0.001$ \\
\hline
\end{tabular}

A two-way ANOVA was used to test AMF effect, shade levels and their interactions but only presented for parameters with the significant effect (the whole effect was presented in the supporting information). Except for gas exchange, all traits were measured and/or calculated after the harvest. Significant after Bonferroni correction was in bold

greater $\mathrm{N}, \mathrm{P}$, and $\mathrm{K}$ mass fractions in roots compared with their corresponding shoots.

\subsection{AM fungal colonization}

Apricot seedlings with shade at different transplantation ages were responsive to mycorrhiza. Arbuscular, hyphal colonization, and mycorrhizal root length were significantly higher in the 5th year compared with the 1 st or $3 \mathrm{rd}$ year (Table 3).

\subsection{Gas exchange}

Apricot transplantation age, mycorrhizae, and shade were all significant sources of variation for $\mathrm{G}_{\mathrm{s}}$, and the interactions between age and shade or between mycorrhiza and shade were also significant (Table S1). $P_{\mathrm{n}}$ and WUE of the 5 th year seedlings were significantly affected by mycorrhiza, shade, and interaction (Table 4 ). $T_{\mathrm{r}}$ was also affected by mycorrhiza or shade, and their interaction was highly significant. Mycorrhizal seedlings with NS had significantly lower $P_{\mathrm{n}}$ and $T_{\mathrm{r}}$ than LS or DS did, and demonstrated opposing trends in $G_{\text {s }}$ (Table 4). Similarly, the WUE of mycorrhizal seedlings was greater than that of non-mycorrhizal seedlings, and in LS it was higher compared with NS or DS (Table 4). Moreover, the $G_{\mathrm{s}}$ of mycorrhizal seedlings was higher than that of non-mycorrhizal seedlings at each shade level. The $G_{\mathrm{s}}$ and WUE were moderately negatively correlated, and significant differences were observed in the apricot leaf area (at the same age) with different treatments (Table 4).

\section{Discussion}

In the present study, AM fungal symbiosis exerted a positive effect on apricot seedling growth. Higher mycorrhizal responsiveness of apricot seedlings in the coalfields was observed, especially for LS. N, P, and K mass fractions in the shoots and roots of mycorrhizal seedlings were higher than those of non-mycorrhizal seedlings, suggesting that such positive mycorrhizal effects were caused by nutrition. Moreover, the beneficial effect of AM fungal symbiosis was greater in LS than in NS or DS conditions.

NS or DS had a relatively negative effect on non-mycorrhizal seedlings. While LS improved mycorrhizal seedling performance compared with non-mycorrhizal seedlings and this effect became stronger over time. This 


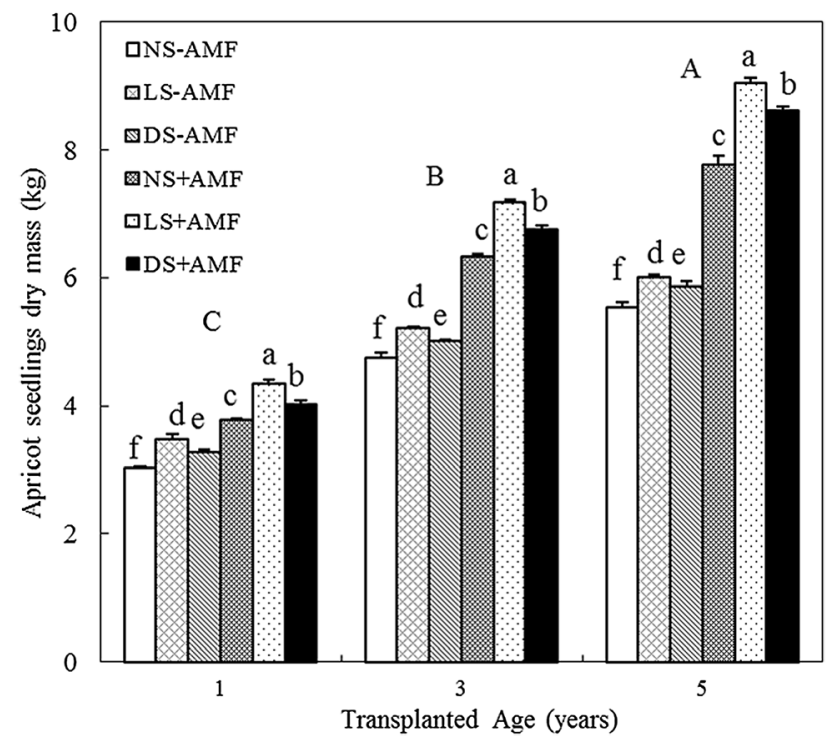

Fig. 2 Effects of AMF and shade treatment on apricot seedling mass (mean $\pm \mathrm{SD})$. Arbuscular mycorrhizal treatment ( $+\mathrm{AMF})$ is compared with inoculation without AMF (- AMF), and a light shade (LS) and a deep shade (DS) are compared with natural light (NS) in the growing stage. Consequently, there were significant differences in seedling biomass between the 1, 3, and 5 year groups. Different capital letters indicate significant differences among transplant age; different lowercase letters (per transplanted age) indicate significant differences between treatments in the same year $(P<0.05)$

result confirmed that mycorrhizal symbiosis played an essential role in cases where there was unpredictable light intensity. Both leaf area and $P_{\mathrm{n}}$ were greatest in mycorrhizal seedlings experiencing LS because AM fungal symbiosis significantly increases root biomass and root length, resulting in increased nutrient storage (Porras-Soriano et al. 2009). Storage of nutrients by seedlings can maintain their stomata open, increasing $P_{\mathrm{n}}$ and $T_{\mathrm{r}}$. Mycorrhizal fungus, combined with LS, triggered the major changes in leaf area, root biomass, and $P_{\mathrm{n}}$, which positively affects the growth of plants (Cutlan et al. 1997; Erhioui et al. 1997).
Besides larger seedlings and improved nutrient storage of mycorrhizal seedlings, we noted an increase in assimilation (in combination with LS), $G_{\mathrm{s}}$, and $T_{\mathrm{r}}$. This phenomenon has been repeatedly observed because significantly higher nutrient was found in the mycorrhizal plants (Chapin et al. 1987; Augé 2001; BassiriRad et al. 2001). For instance, Querejeta et al. (2003) found that AM fungi enhanced $G_{\mathrm{s}}$ levels in the slow-growing Olea europaea L. ssp. sylvestris compared with the fast-growing Rhamnus lycioides, suggesting that this species can survive in adverse environments (Querejeta et al. 2003). Moreover, non-mycorrhizal plants have lower photosynthetic activity and light-saturated $G_{\mathrm{s}}$ in grasslands (Pierik et al. 2006; Valladares et al. 2007). The deep shade reduced $P_{\mathrm{n}}$ in nonmycorrhizal compared with mycorrhizal seedlings. AM fungal symbiosis conferred resistance to light reduction, and higher leaf stomatal closing capacity was an adaptive mechanism of shade. Similarly, both herbs and shrubs affect stomatal changes under deep light intensity (Kim et al. 2011). Moreover, Baruch and Goldstein (1999) noted that $G_{\mathrm{s}}$ strongly increased in shade-adapted species compared with other species. The increase in $G_{\mathrm{s}}$ of shadeadapted mycorrhizal species is consistent with greater nutrient facilitation (Baruch and Goldstein 1999). A significant effect of AM fungal species has also been reported by Schaffer and Mason (1990).

The $G_{\mathrm{s}}$ in mycorrhizal plants increased more than in non-mycorrhizal plants, which would be generally translated into increases in $P_{\mathrm{n}}$. Moreover, the mycorrhizal plant had remarkably higher $T_{\mathrm{r}}$ with LS compared with nonmycorrhizal plants, which improved WUE. Considering the complex structure of roots, it was likely that roots had a higher WUE because of more fine root hairs. Furthermore, LS increased $G_{\mathrm{s}}$ and assimilation, but the increase in $T_{\mathrm{r}}$ was smaller. Consequently, WUE was higher compared with non-mycorrhizal plants with LS.

Mycorrhizal seedling $P_{\mathrm{n}}$ was enhanced by $17.2 \%$, and greater carbon fractions were allocated to soil (Wang et al. 2016). Similarly, mycorrhizal seedlings stored more

Table 3 Fractional mycorrhizal colonization rate and mycorrhizal root lengths for inoculated apricot seedlings

\begin{tabular}{|c|c|c|c|c|c|c|c|c|c|c|c|c|}
\hline \multirow{2}{*}{$\begin{array}{l}\text { Colonization } \\
\text { Percentage }\end{array}$} & \multicolumn{5}{|l|}{ Age } & \multicolumn{5}{|l|}{ Shade } & \multicolumn{2}{|c|}{ Age $\times$ Shade } \\
\hline & 1 & 3 & 5 & $F$ & $P$ & NS & LS & DS & $F$ & $P$ & $F$ & $P$ \\
\hline Arbuscular colonization & $0.40 \mathrm{~b}$ & $0.46 b$ & $0.53 \mathrm{a}$ & 8.37 & 0.005 & $0.34 \mathrm{~b}$ & $0.57 \mathrm{a}$ & $0.38 b$ & 7.851 & 0.008 & 5.32 & 0.009 \\
\hline Vesicular colonization & $0.73 \mathrm{a}$ & $0.76 \mathrm{a}$ & $0.77 \mathrm{a}$ & 7.06 & 0.002 & $0.54 \mathrm{a}$ & $0.65 \mathrm{a}$ & $0.67 \mathrm{a}$ & 6.785 & 0.011 & 5.03 & 0.018 \\
\hline Hyphal colonization & $0.57 \mathrm{c}$ & $0.73 b$ & $0.93 \mathrm{a}$ & 8.7 & 0.001 & $0.55 \mathrm{c}$ & $0.96 \mathrm{a}$ & $0.71 b$ & 19.63 & 0.006 & 4.58 & 0.016 \\
\hline Mycorrhizal root length & $10.5 \mathrm{c}$ & $19.8 \mathrm{~b}$ & $28.7 \mathrm{a}$ & 6.98 & 0.003 & $12.2 \mathrm{c}$ & $27.9 \mathrm{a}$ & $18.9 \mathrm{~b}$ & 15.45 & 0.004 & 5.65 & 0.005 \\
\hline
\end{tabular}

A two-way ANOVA is used to test for the effect of age and shade and their interactions. The significances were in bold. Different lowercase letters denote significant differences among the different samples 
Table 4 Physiological characteristics as affected by AMF and shade levels in 5 years apricot seedlings

\begin{tabular}{|c|c|c|c|c|c|}
\hline Treatment & Leaf area $\left(\mathrm{cm}^{2}\right)$ & $P_{\mathrm{n}}\left(\mu \mathrm{mol} \mathrm{m}{ }^{-2} \mathrm{~s}^{-1}\right)$ & 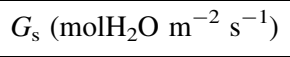 & $T_{\mathrm{r}}\left(\mathrm{mmol} \mathrm{m}{ }^{-2} \mathrm{~s}^{-1}\right)$ & WUE $(\mu \mathrm{mol} / \mathrm{mol})$ \\
\hline NS-AMF & $7.96 \pm 1.25 \mathrm{e}$ & $4.15 \pm 0.86 \mathrm{~d}$ & $0.219 \pm 0.026 \mathrm{c}$ & $2.89 \pm 0.73 c$ & $5.24 \pm 0.69 \mathrm{e}$ \\
\hline LS-AMF & $8.62 \pm 1.56 \mathrm{~d}$ & $5.11 \pm 1.09 \mathrm{c}$ & $0.165 \pm 0.034 \mathrm{~d}$ & $3.12 \pm 0.64 \mathrm{c}$ & $6.38 \pm 1.29 \mathrm{~d}$ \\
\hline DS-AMF & $8.33 \pm 0.86 \mathrm{~d}$ & $5.03 \pm 0.82 \mathrm{c}$ & $0.133 \pm 0.029 \mathrm{e}$ & $4.56 \pm 0.63 b$ & $6.45 \pm 0.88 \mathrm{~d}$ \\
\hline $\mathrm{NS}+\mathrm{AMF}$ & $9.13 \pm 1.08 \mathrm{c}$ & $7.58 \pm 1.33 b$ & $0.328 \pm 0.056 \mathrm{a}$ & $4.63 \pm 0.82 b$ & $9.97 \pm 0.75 c$ \\
\hline $\mathrm{LS}+\mathrm{AMF}$ & $11.29 \pm 2.25 \mathrm{a}$ & $11.85 \pm 2.69 \mathrm{a}$ & $0.276 \pm 0.058 b$ & $6.03 \pm 1.35 \mathrm{a}$ & $13.46 \pm 0.88 \mathrm{a}$ \\
\hline $\mathrm{DS}+\mathrm{AMF}$ & $10.12 \pm 1.68 b$ & $8.38 \pm 1.68 b$ & $0.207 \pm 0.047 \mathrm{~cd}$ & $5.87 \pm 0.63 \mathrm{a}$ & $11.33 \pm 0.95 b$ \\
\hline Inoculation (I) & 0.002 & $\mathbf{0 . 0 3 3}$ & $<0.001$ & 0.002 & 0.043 \\
\hline Shade (S) & $<\mathbf{0 . 0 0 1}$ & $<0.001$ & $<0.001$ & $<0.001$ & $\mathbf{0 . 0 3 3}$ \\
\hline $\mathrm{I} \times \mathrm{S}$ & $<0.001$ & 0.015 & 0.002 & 0.027 & 0.007 \\
\hline
\end{tabular}

Values are means of three replicates. Values followed by the same lowercase letters in the same columns are not significantly different among different treatments for one indicator in one year at the 5\% level by LSD (vertical comparison). Values under ANOVA are the probabilities $(P)$ of variation source. The significances were in bold

resources in roots as a nutrient circulation or conservation strategy. Simard et al. (2012) also showed that mycorrhizal oak savanna has more photosynthetic products and a greater amount of substance transported from leaves to roots, subsequently benefiting the mycelium of mycorrhizal fungi. Molecular evidence indicated that shaded seedlings had changes in the expression of critical transporters, MdARF6 and MdARF106, which possess greater nutrients or photosynthetic products (Dash et al. 2012). Therefore, this was able to explain the storage of nutrients or carbohydrate production in roots or shoots. Moreover, mycorrhizal had significantly higher $T_{\mathrm{r}}$ compared with nonmycorrhizal plants, and hyphae transported nutrients to roots, which also maintained mycorrhizal colonization, similar to that observed in greenhouse-grown plants (Cozzolino et al. 2016).

Suitable light intensities could help mycorrhizal seedlings to sequester resources in the next growing season compared with non-mycorrhizal seedlings because apricot leaves fall back into the soil during the winter season, increasing nutrient amounts (especially for carbon storage). A similar behavior has been observed in eucalypt trees (Jackson and Ash 2001). Therefore, more robust growth further improved the carbon and nutrient cycle in seedlings, where mycorrhiza accelerated the land reclamation process, and this finally reached an optimal status that benefited the coalfield ecology.

\section{Conclusions}

Arbuscular mycorrhizal symbiosis with LS enhanced productivity and nutrients in leaves and roots as well as seedling performance. Interaction studies showed that LS benefited mycorrhizal apricot seedlings. Briefly, LS enhanced leaf area and nutrient storage in mycorrhizal seedlings, resulting in the highest assimilation rate. Similarly, WUE and $T_{\mathrm{r}}$ were also increased in mycorrhizal species. Moreover, AM symbiosis led to greater resourcestorage in roots and facilitated the restoration of subsidence land. Therefore, AM fungi were greatly associated with nutrient gain, and this allowed for greater resources to offset the negative influences. This practice is essential for the sustainable management of ecologically important species and provides new ideas for plant-soil interactions. Future studies should investigate how interactions between AM fungi and shade affect competition among different species.

Acknowledgements We thank the National Natural Science Foundation of China (51974326) and Capital Science and Technology Talents Training Project (Beijing) (Z18110006318021). We greatly appreciate three local farmers for their fieldwork assistance.

Open Access This article is licensed under a Creative Commons Attribution 4.0 International License, which permits use, sharing, adaptation, distribution and reproduction in any medium or format, as long as you give appropriate credit to the original author(s) and the source, provide a link to the Creative Commons licence, and indicate if changes were made. The images or other third party material in this article are included in the article's Creative Commons licence, unless indicated otherwise in a credit line to the material. If material is not included in the article's Creative Commons licence and your intended use is not permitted by statutory regulation or exceeds the permitted use, you will need to obtain permission directly from the copyright holder. To view a copy of this licence, visit http://creativecommons. org/licenses/by/4.0/.

Author contributions YB conceived and designed the experiments; ZW performed the experiments; LX and KW analyzed the data; the manuscript was written with the help of all the authors.

Availability of data and materials The datasets used and analyzed during the current study are available from the corresponding author upon request. 


\section{References}

Allen EB, Allen MF (1980) Natural re-establishment of vesiculararbuscular mycorrhizae following strip mine reclamation in Wyoming. J Appl Ecol 17:139-147. https://doi.org/10.2307/ 240296

Augé M (2001) Water relations, drought, and vesicular-arbuscular mycorrhizal symbiosis. Mycorrhiza 11:3-42. https://doi.org/10. 1007/s005720100097

Baruch Z, Goldstein G (1999) Leaf construction cost, nutrient concentration, and net $\mathrm{CO}_{2}$ assimilation of native and invasive species in Hawaii. Oecologia 121:183-192. https://doi.org/10. 1007/s004420050920

BassiriRad H, Gutschick VP, Lussenhop J (2001) Root system adjustments: regulation of plant nutrient uptake and growth responses to elevated $\mathrm{CO}_{2}$. Oecologia 126:305-320. https://doi. org/10.1007/s004420000524

Becklin KM, Pallo ML, Galen C (2012) Willows indirectly reduce arbuscular mycorrhizal fungal colonization in understory communities. J Ecol 100:343-351. https://doi.org/10.1111/j.13652745.2011.01903.x

Bi Y, Zhang Y, Zou H (2018) Plant growth and their root development after inoculation of arbuscular mycorrhizal fungi in coal mine subsided areas. Int J Coal Sci Technol 5:47-53. https://doi.org/10.1007/s40789-018-0201-x

Bi Y, Xiao L, Liu R (2019) Response of arbuscular mycorrhizal fungi and phosphorus solubilizing bacteria to remediation abandoned solid waste of coal mine. Int J Coal Sci Technol 6:603-610. https://doi.org/10.1007/s40789-019-00270-7

Bi Y, Guo C, Wang K (2020) Research progress of biological improvement of reclaimed soil in coal mining area. Coal Sci Technol 4:52-59

Binu NK, Ashokan PK, Balasundaran M (2015) Influence of different arbuscular mycorrhizal fungi and shade on growth of sandal (Santalum album) seedlings. J Trop For Sci 27:158-165

Boardman NK (1977) Comparative photosynthesis of sun and shade plants. Ann Rev Plant Physiol 28:355-377. https://doi.org/10. 1146/annurev.pp.28.060177.002035

Brundrett M (2004) Diversity and classification of mycorrhizal associations. Bio Rev 79:473-495. https://doi.org/10.1017/ S1464793103006316

Carminati A (2013) Rhizosphere wettability decreases with root age: a problem or a strategy to increase water uptake of young roots? Front Plant Sci 4:1-9. https://doi.org/10.3389/fpls.2013.00298

Chapin FS, Bloom AJ, Field CB, Waring RH (1987) Plant responses to multiple environmental factors. Bioscience 37:49-57. https:// doi.org/10.2307/1310177

Cozzolino V, Di Meo V, Monda H, Spaccini R, Piccolo A (2016) The molecular characteristics of compost affect plant growth, arbuscular mycorrhizal fungi, and soil microbial community composition. Biol Fert Soils 52:15-29. https://doi.org/10.1007/ s00374-015-1046-8

Cutlan A, Nordwig G, Warner R, Erwin JE (1997) Red/far red light and PAR leaf absorption varies among hanging basket crop species. HortScience 32:502-506. https://doi.org/10.21273/ HORTSCI.32.3.502E

Dash M, Johnson LK, Malladi A (2012) Severe shading reduces early fruit growth in apple by decreasing cell production and expansion. J Am Soc Hortic Sci 137:275-282. https://doi.org/ 10.21273/JASHS.137.5.275

Erhioui MB, Dorais M, Gosselin A, Papadopulos AP (1997) Effects of supplemental light on growth, photosynthesis, and carbohydrates synthesis in the leaves of tomato (Lycopersiconesculentum L.) grown under different greenhouse covering materials.
HortScience 32:480-481. https://doi.org/10.21273/HORTSCI. 32.3.480F

Espeleta JF, West JB, Donovan LA (2009) Tree species fine-root demography parallels habitat specialization across a sandhill soil resource gradient. Ecol 90:1773-1787. https://doi.org/10.1890/ 08-0056.1

Giovannetti M, Mosse B (1980) An evaluation of techniques for measuring vesicular arbuscular mycorrhizal infection in roots. New Phytol 84:489-500

Heinemeyer A, Ridgway KP, Edwards EJ, Benham DG, Young JPW, Fitter AH (2004) Impact of soil warming and shading on colonization and community structure of arbuscular mycorrhizal fungi in roots of a native grassland community. Global Change Biol 110:52-64. https://doi.org/10.1111/j.1365-2486.2003. 00713.x

Hodge A, Fitter AH (2010) Substantial nitrogen acquisition by arbuscular mycorrhizal fungi from organic material has implications for $\mathrm{N}$ cycling. Proc Natl Acad Sci USA 107:13754-13759. https://doi.org/10.1073/pnas.1005874107

Hunt R, Cornelissen JHC (1997) Components of relative growth rate and their interrelations in 59 temperate plant species. New Phytol 135:395-417. https://doi.org/10.1046/j.1469-8137.1997.00671.x

Jackson J, Ash AJ (2001) The role of trees in enhancing soil nutrient availability for native perennial grasses in open eucalypt woodlands of north-east Queensland. Crop Pasture Sci 52:377-386. https://doi.org/10.1071/AR00012

Jia X, Zhao C, Wang Y, Zhu Y, Wei X, Shao MA (2020) Traditional dry soil layer index method overestimates soil desiccation severity following conversion of cropland into forest and grassland on China's Loess Plateau. Agric Ecosyst Environ 291:106794. https://doi.org/10.1016/j.agee.2019.106794

Kaschuk G, Kuyper TW, Leffelaar PA, Hungria M, Giller KE (2009) Are the rates of photosynthesis stimulated by the carbon sink strength of rhizobial and arbuscular mycorrhizal symbioses? Soil Biol Biochem 41:1233-1244. https://doi.org/10.1016/j.soilbio. 2009.03.005

Kim SJ, Yu DJ, Kim TC, Lee HJ (2011) Growth and photosynthetic characteristics of blueberry (Vacciniumcorymbosum cv. Bluecrop) under various shade levels. Sci Hortic 129:486-492. https://doi.org/10.1016/j.scienta.2011.04.022

Kubien DS, Von Caemmerer S, Furbank RT, Sage RF (2003) C4 photosynthesis at low temperature. A study using transgenic plants with reduced amounts of Rubisco. Plant Physiol 132:1577-1585. https://doi.org/10.1104/pp.103.021246

Landis FC, Gargas A, Givnish TJ (2004) Relationships among arbuscular mycorrhizal fungi, vascular plants and environmental conditions in oak savannas. New Phytol 164:493-504. https:// doi.org/10.1111/j.1469-8137.2004.01202.x

Landis FC, Gargas A, Givnish TJ (2005) The influence of arbuscular mycorrhizae and light on Wisconsin (USA) sand savanna understories 2. Plant Competition. Mycorrhiza 15:555-562. https://doi.org/10.1007/s00572-005-0365-2

Lechner AM, Baumgartl T, Matthew P, Glenn V (2016) The impact of underground longwall mining on prime agricultural land: a review and research agenda. Land Degrad Dev 27:1650-1663. https://doi.org/10.1002/ldr.2303

Levy MA, Cumming JR (2014) Development of soils and communities of plants and arbuscular mycorrhizal Fungi on West Virginia surface mines. Environ Manag 54:1153-1162. https:// doi.org/10.1007/s00267-014-0365-0

Lichtenthaler HK, Buschmann C, Döll M, Fietz HJ, Bach T, Kozel U, Meier D, Rahmsdorf U (1981) Photosynthetic activity, chloroplast ultrastructure, and leaf characteristics of high-light and low-light plants and of sun and shade leaves. Photosynth Res 2:115-141. https://doi.org/10.1007/BF00028752 
Mehrotra VS (1998) Arbuscular mycorrhizal associations of plants colonizing coal mine spoil in India. J Agric Sci 130:125-133. https://doi.org/10.1017/S0021859697005091

Niinemets Ü (2007) Photosynthesis and resource distribution through plant canopies. Plant Cell Environ 30:1052-1071. https://doi. org/10.1111/j.1365-3040.2007.01683.x

Niinemets Ü, Valladares F (2004) Photosynthetic acclimation to simultaneous and interacting environmental stresses along natural light gradients: optimality and constraints. Plant Biol 16:254-268. https://doi.org/10.1055/s-2004-817881

Pierik R, Tholen D, Poorter H, Visser EJ, Voesenek LA (2006) The Janus face of ethylene: growth inhibition and stimulation. Trends Plant Sci 11:176-183. https://doi.org/10.1016/j.tplants.2006.02. 006

Porras-Soriano A, Soriano-Martín ML, Porras-Piedra A, Azcón R (2009) Arbuscular mycorrhizal fungi increased growth, nutrient uptake and tolerance to salinity in olive trees under nursery conditions. J Plant Physiol 166:1350-1359. https://doi.org/10. 1016/j.jplph.2009.02.010

Püschel DJ, Rydlová J, Vosátka M (2008) Does the sequence of plant dominants affect mycorrhiza development in simulated succession on spoil banks? Plant Soil 302:273-282. https://doi.org/10. 1007/s11104-007-9480-5

Querejeta JI, Barea JM, Allen MF, Caravaca F, Roldán A (2003) Differential response of $\delta^{13} \mathrm{C}$ and water use efficiency to arbuscular mycorrhizal infection in two arid land woody plant species. Oecologia 135:510-515. https://doi.org/10.1007/ s00442-003-1209-4

Schaffer B, Mason B (1990) Effects of scale insect herbivory and shading on net gas exchange and growth of a subtropical tree species (Guaiacum sanctum L.). Oecologia 84:468-473

Simard SW, Beiler KJ, Bingham MA, Deslippe JR, Philip LJ, Teste FP (2012) Mycorrhizal networks: mechanisms, ecology and modeling. Fungal Biol Rev 26:39-60. https://doi.org/10.1016/j. fbr.2012.01.001
Smith SE, Facelli E, Pope S, Smith FA (2010) Plant performance in stressful environments: interpreting new and established knowledge of the roles of arbuscular mycorrhizas. Plant Soil 326:3-20. https://doi.org/10.1007/s11104-009-9981-5

Tennant D (1975) A test of a modified line intersect method of estimating root length. J Ecol 63:995-1001. https://doi.org/10. $2307 / 2258617$

Valladares F, Gianoli E, Gómez JM (2007) Ecological limits to plant phenotypic plasticity. New Phytol 176:749-763. https://doi.org/ 10.1111/j.1469-8137.2007.02275.x

Wang ZG, Bao XG, Li XF, Jin X, Zhao JH, Sun JH, Christie P, Li L (2015) Intercropping maintains soil fertility in terms of chemical properties and enzyme activities on a time scale of one decade. Plant Soil 391:265-282. https://doi.org/10.1007/s11104-0152428-2

Wang ZG, Bi YL, Jiang B, Zhakypbek Y, Peng SP, Liu WW, Liu H (2016) Arbuscular mycorrhizal fungi enhance soil carbon sequestration in the coalfields, northwest China. Sci Rep 6:34336. https://doi.org/10.1038/srep34336

Wang J, Wang P, Qin Q, Wang H (2017) The effects of land subsidence and rehabilitation on soil hydraulic properties in a mining area in the Loess Plateau of China. CATENA 159:51-59. https://doi.org/10.1016/j.catena.2017.08.001

Wielicki BA, Harrison EF, Cess RD, King MD, Randall DA (1995) Mission to planet earth: role of clouds and radiation in climate. Bull Am Meteorol Soc 76:2125-2153

Yan XF, Wang Y, Shang XH, Guo ST, Yu T (2004) Effects of field light intensity and quality on biomass and salidroside content in roots of Rhodiola sachalinensis in fiele. Acta Ecol Sin 24:674-679

Yu GH, Man HM, Luo WX (1994) Effect of light intensity on photosynthetic characteristics, nutritive components and yield of American ginseng. J Appl Ecol 5:57-61

Zhang Y, Bi Y, Wang J (2020) Research on effect of arbuscular mycorrhizal fungi on alfalfa growth and soil improvement in mining subsidence area. Coal Sci Technol 4:142-147 